\title{
Recenzja
}

\section{Tomasz Sypniewski, Rada Państwa w systemie organów władzy państwowej Polski Ludowe (1947-1989), Dom Wydawniczy Duet, Toruń 2010, ss. 419}

Instytucja Rady Państwa, zarówno działającej na gruncie Małej Konstytucji z 1947 r., jak również funkcjonującej w oparciu o Konstytucję PRL z 1952 r. w latach 1952-1989, doczekała się już wielu opracowań naukowych, głównie artykułowych, ale i książkowych. Szczególnie wartościowa w tym względzie jest monografia J. Stembrowicza. Pochodzi ona jednak z 1968 r., nie uwzględnia zatem ani późniejszych nowelizacji, ani praktyki działania Rady Państwa w pełnym zakresie. Z tym większym zainteresowaniem sięga czytelnik po najnowszą w tej dziedzinie monografię wydaną w 2010 r., a więc pisaną już z większej perspektywy historycznej.

Jest to książka opracowana przez historyka prawa, który przeprowadził szeroko zakreślone studia i badania, w toku których analizował i omawiał niezwykle bogaty materiał źródłowy. Składają się nań archiwalia znajdujące się w Archiwum Akt Nowych, a także w Archiwum Prezydenta Rzeczypospolitej Polskiej, źródła prawa, wydawnictwa źródłowe oraz literaturę. Wykaz tych materiałów zajmuje 12 stron książki.

Autor, będąc historykiem prawa, umiejętnie posługuje się materiałem historycznym, stosując właściwe metody badawcze, wykorzystuje także dorobek doktryny prawa, szczególnie prawa konstytucyjnego.

Monografia składa się ze wstępu, siedmiu rozdziałów, zakończenia, a także aneksów. Najobszerniejszym jest rozdział I Ewolucja ustroju państwowego Polski Ludowej w okresie 1944-1989. Znalazła tu wyraz pasja historyka, widoczna w toku omawiania i charakterystyki tych lat, politycznych i społecznych wydarzeń, niezależnie od tego czy i jak silnie są one związane z problematyką określoną w tytule monografii. Dla podjętego w monografii tematu nie tak ważna była kwestia jak doszło do uchwalenia Konstytucji PRL, czy charakterystyka poszczególnych grup organów składających się na aparat państwa. Zawarta w tym rozdziale problematyka nie jest wprawdzie obojętna dla omawianych kwestii, ale rozdział zyskałby, gdyby był ujęty bardziej 
syntetycznie. Gdyby autor tak postąpił uniknąłby kilku błędów. Na s. 62 jest informacja, iż PKWN posiadał prawo wydawania dekretów z mocą ustawy na podstawie ustawy z dnia 3 stycznia 1945 r., podczas gdy organ ten przestał istnieć już dnia 31 grudnia 1944 r. Niezbyt kompletna jest charakterystyka polityczna grup natolińskiej i puławskiej w PZPR (s. 27). Błędna jest data dotycząca przedłużenia kadencji Sejmu Ustawodawczego (s. 70). Omawiając przepisy ordynacji wyborczej z 1946 r. (s. 68) słusznie zarzuca jej niedemokratyczne rozwiązania $\mathrm{w}$ zakresie prawa pozbawiania obywateli praw wyborczych, ale czy należało to odnieść także do osób przyznających się do narodowości niemieckiej, lub zaliczanych do grupy uprzywilejowanych przez okupanta? (s. 69) lub czerpiących korzyści ze współpracy z władzami okupacyjnymi? Na s. 89, omawiając nowelizację Konstytucji PRL w wyniku porozumień „okrągłego stołu”, nazywa zmianę trybu działania Sejmu z sesyjnego na permanentny, stwierdza, że obrady miały się toczyć „nieustannie”. Są to pewne niezręczności natury redakcyjnej, ale nie zostały poprawione w trakcie korekty czy adiustacji.

Treść rozdziału I jest wyraźnie rozbudowana, z mocnym akcentowaniem stosunków społeczno-politycznych ze szkodą dla bardziej zwięzłego omawiania problematyki prawno-ustrojowej. Dostrzega się brak omówienia prawnych podstaw działania władz ówczesnych, ich stosunku do konstytucji z okresu II Rzeczypospolitej Polskiej.

Rozdział II służy omówienia charakteru prawnego i roli pierwszej Rady Państwa, działającej na podstawie Małej Konstytucji z 1947 r. Zawiera on wiele interesujących rozważań dotyczących składu, powoływania i odwoływania członków. Są to rozważania wnikliwe i w pełni zasadne.

Omawianie kompetencji RP stworzyło okazję do wykazania istnienia wielu luk w zakresie regulacji dotyczących organizacji i funkcjonowania $\mathrm{RP}$ - np. kwestii odpowiedzialności konstytucyjnej członków tego organu, co z uwagi na zakres kompetencji i tendencje do jego poszerzania umacniało rolę ustrojową Rady Państwa.

Także w tym rozdziale spotyka się pewne nieścisłości - i tak na s. 119 w przypisie 40 ustawę z dnia 11 września 1944 r. o radach narodowych określa się jako dekret z mocą ustawy.

Rozdział III zawiera rozważania dotyczące Rady Państwa działającej w latach 1952-1989, określanej jako druga RP. Rozdział zawiera wiele wątków wykraczających poza temat np. odpowiedników Rady Państwa istnieją- 
cych w innych państwach socjalistycznych. Ściśle natomiast $\mathrm{z}$ tematem związane są uwagi o miejscu RP w systemie organów państwowych, strukturze, funkcjach tego organu.

Omawiając skład RP autor wymienia imiennie jej członków i omawia ich rolę w życiu politycznym państwa oraz funkcjonowaniu RP.

Podkreślić należy, że bardzo duża część rozważań zawartych w tym rozdziale stanowi ciekawe informacje, których dotąd nie poruszano w literaturze naukowej czy w innych dostępnych publikacjach. Dotyczy to szczególnie trybu działania RP, struktury jej organów wewnętrznych, roli komisji, ich liczby, wykonywanych zadań.

$\mathrm{W}$ rozdziale tym znajdujemy dwie niezręczności natury redakcyjnej. $\mathrm{Na}$ s. 133 występuje stwierdzenie o konstruowaniu przez Sejm składu personalnego Rady Ministrów, wszak w praktyce była to z jego strony zwykła formalność, skoro decyzje w tym zakresie podejmowano w kierownictwie PZPR. Podobną nieścisłość spotykamy na s. 164, gdzie czytamy, że RP posiadała uprawnienia w zakresie „nadzoru a nawet kontroli”, jak gdyby pojęcie kontroli miało szerszy zakres treści niż nadzór. Niezbyt też ścisłe są uwagi autora na s. 163 dotyczące prawa łaski, a także amnestii.

Rozdział IV został poświęcony kluczowej dla tematu kwestii relacji Rada Państwa-Sejm. Przedmiotem rozważań autora stały się zarówno kompetencje własne RP, wyraźnie jej powierzone i wykonywane w sposób wyłączny i samodzielny, a także uprawnienia przyznane jej w zastępstwie Sejmu. Rozważania te są prowadzone w oparciu o przepisy Konstytucji PRL, ale także w świetle praktyki. Wiele uwagi poświęca autor, dochodząc do trafnych ocen i wniosków, omawiając kompetencje RP w zakresie tworzenia prawa (inicjatywa ustawodawcza, stanowienie dekretów z mocą ustawy), powszechną wykładnią prawa, a także kontrolą zgodności norm prawnych z konstytucją.

Rozdział V Rada Państwa a terenowe organy przedstawicielskie to najmniejszy objętościowo fragment monografii. Ma on za cel omówienie roli RP w zakresie przede wszystkim nadzoru w systemie rad narodowych i ich organów wykonawczych.

$W$ rozdziale VI autor porusza problematykę kompetencji RP jako głowy państwa, koncentrując się głównie na praktyce podejmowanych w tym charakterze działań (nominacje profesorskie, decyzje kreacyjne, powoływanie sędziów, prokuratorów, nadawanie stopni wojskowych, orderów i odznaczeń państwowych (błędnie podano na s. 317 nazwę Orderu Odrodzenia Polski), 
sprawy obywatelstwa, stosowanie prawa łaski i uprawnienia w zakresie stanów nadzwyczajnych).

Rozdział VII został zatytułowany Rada Państwa a pozostałe organy państwowe - w tym przede wszystkim Rada Ministrów, ale także Sąd Najwyższy, Prokurator Generalny, NIK, Naczelna Rada Adwokacka, Państwowa Inspekcja Pracy, Główny Urząd Kontroli Prasy i Widowisk, a także związki zawodowe. Kompetencje w tym zakresie dotyczą nie tylko organów państwowych. Rozważania te dotyczą nie tylko obowiązujących regulacji prawnych ale i szeroko pojmowanej praktyki, którą badał bardzo wnikliwie.

Monografię zamyka zakończenie, podsumowujące przeprowadzane rozważania.

Autor często na określenie Rady Państwa używa terminu „organ prezydialny”, podobnie jak to się dzieje w literaturze byłych państw socjalistycznych, jednak RP różniła się od takich organów jak Prezydium Rady Najwyższej ZSRR i brak uzasadnienia dla posługiwania się nim w Polsce. Właściwsze już wydaje się używanie nazwy - organ typu prezydialnego.

Dostrzegać należy zalety monografii, ale dotyczą one głównie strony merytorycznej, gorzej wygląda strona formalna. Wiele jest błędów i usterek w pisowni nazwisk, co świadczy o niedbałej korekcie tekstu, wiele nazwisk zniekształcono np. Piaskowski zamiast Pińkowski (s. 48), Peretiakowicz zamiast Peretiatkowicz (s. 417), Szlachciak zamiast Szlachcic (s. 378), Ciborski zamiast Ciborowski (s. 370), Chełkowski zamiast Chełchowski (s. 48), Dubiel zamiast Dubel (s. 213). Są też innego rodzaju usterki jak np. błędna data morderstwa ks. Popiełuszki (s. 52), a także data kadencji Sejmu Ustawodawczego (s. 76, 79). W tekście wielokrotnie użyty został „chwast językowy” w postaci określenia „zapis ustawy”, czego szanujący się prawnik nie powinien czynić, gdyż termin ten stosowany jest na oznaczenie różnych pojęć - przepis, norma prawna, artykuł itp. a są to przecież pojęcia różnoznaczne.

W sposób dowolny pisane są nazwy różnych organów państwowych, np. spotyka się sejm i Sejm, prokurator generalny, ale Prezydium Rady Narodowej. Wspominam o tych usterkach z obowiązku recenzenckiego, choć czynię to $\mathrm{z}$ żalem, gdyż autor włożył wiele wysiłku w przeprowadzenie badań naukowych i opracowanie monografii.

Wiesław Skrzydło (Uniwersytet Marii Curie-Skłodowskiej w Lublinie) 